\title{
BACK TO THE YEAR WHEN IT ALL STARTED: LOCAL DETERMINANTS OF PARTY PREFERENCES IN 2002 TURKISH ELECTIONS Oğuz IŞIK and M. Melih PINARCIOĞLU
}

Received: 12.06.2009, Final Text: 04.01.2010

Keywords: Turkey; geographically weighted regression; centre-periphery model; party preferences; political parties.

1. The maps in this article use geographical coordinate system (latitudes andlongitudes) based on WGS 84 (World Geodetic System) ellipsoid.

2. See for instance Smith (2005) and Mecham (2004).

\section{INTRODUCTION}

The ruling Justice and Development Party (AKP) won the 2007 general elections in Turkey by a large margin and became the first party since the 1980s to increase its votes in two consecutive elections while in power (1). Although the elections were held in a highly tense political climate arising from controversy surrounding the presidential elections (Bacik, 2008), the results came as no surprise to many and received far less attention in the media, academia and public compared to the previous elections held in 2002. The exceptionally low turnout rate of $59.3 \%$, as opposed to $84.3 \%$ in 2002, is one of the obvious indications of low public interest in the elections.

Looking backwards, many would agree now that it was the 2002 elections that represented the major turn in Turkish politics. There are a number of factors that make these elections unique. The first is certainly the victory of a party described by many as "Islamist-leaning" (Kanra, 2005, 515) or representing "moderate political Islam" (Çaha, 2003). The victory of AKP, which had been established merely 15 months before the elections and whose president had been in jail some time ago for publicly reciting a poem, took almost everyone by surprise, even those who were accustomed to the ups and downs of politics in Turkey. Described as a "political earthquake" (Gruen, 2003) and even as a "tsunami" (Özel, 2003), the impacts of the 2002 elections on society are indeed comparable to the year 1950 when the three-decade single-party rule came to an end or to the year 1980 when both the coup d'etat and liberal turn of the economy took place. The ascent to power of a party whose origins were undeniably connected with the politicization of Islam attracted worldwide attention and brought to the fore some burning questions on the compatibility of Islam and democracy in the post $9 / 11$ world (2).

It was not only the victory of a party rooted in Islamist movement in a country that had "a longer history of secularism than any other Muslim 
3. For an analysis of the geography of 2002 and previous elections at the national level, Işık and Pınarcıoğlu, (2006a). See also Işık and Pınarcoğlu (2006c) for the analysis 2002 elections in the case of Ankara. country" (Hermann, 2003, 266) that made these elections unique. All the parties represented in the parliament, either in power or in opposition, in the previous 1999 elections failed to pass the national threshold. All the parties that took part in the governing three-party coalition, and the opposition party, all representing the well-established traditions in Turkish politics and all of which had been major actors of the political arena after the 1980 military takeover, saw humiliating defeat and remained seatless in the parliament. Contributing to the bizarreness of the election was the unexpected $7.2 \%$ of votes received by the Young Party (GP), a new party with no clear political identity (Bacik, 2004), led by a notorious business tycoon, careful to dissociate himself from any established political tradition. Furthermore, the pro-Kurdish People's Democracy Party (DEHAP) received an all-time high of $6.2 \%$ of votes.

Surprising though they certainly were as far as the established political balances are concerned, the results of 2002 elections once again proved the persistence of the well-known geographical pattern of voting in Turkey. This pattern made itself visible, put very briefly, with concentrations of liberal and social democrat parties in western regions, nationalist parties in the centre, Islamist and conservative parties in the east and pro-Kurdish party in the south east (3). The unevenness of spatial voting patterns in Turkey has been well studied and documented in connection with the 2002 and previous elections (Çarkoğlu, 2000; West, 2005). This paper is structured around the objective of going beyond the mere task of documenting the spatial unevenness of party votes and to unearth, with the aid of geographically weighted regression (GWR) technique, the very reasons that may account for why a particular political party received the percentage of votes it did in a particular locality in the 2002 elections. In other words, this is not an article about the geography of voting in Turkey, but about the geography of factors that make political parties' votes differ from one region to another.

Using the district level results of the 2002 elections, we develop a model that could explain the reasons behind this uneven spatial pattern of voting. With this aim we build a two-stage regression model, one global and one local. We start with an ordinary least squares (OLS) regression model to unravel the nation-wide cause-effect relationships between party votes and a number of social and economic indicators. In the next stage, we develop a GWR model with the same variables in an attempt to take into account the spatially changing (contingent) relationships between party votes and independent variables. Allowing the parameters of a regression equation to change locally, GWR depends on the understanding that the very same cause may lead to a different effect in a different context. It is therefore the contextual nature of interaction between a set of variables that GWR tries to uncover. Formulated from another perspective, what we wish to do in this paper is to show that there exist in Turkey, as far as party votes are concerned, regions differentiated from each other not only in terms of the percentage of votes received by each party, but also with regard to the determinants of party preferences in each locality.

In the section that follows we discuss the 2002 elections and make brief remarks about the political parties we enquire in the paper. The third section is devoted to data considerations and building the OLS model. Here we introduce the variables we use in the GWR model. The section that follows comprises the GWR model and the implications that it brings to the fore. In the final section of the paper, we discuss the conclusions flowing out of the analysis we make. 


\section{ELECTIONS AND POLITICAL PARTIES: A BRIEF BACKGROUND}

The origins of the rupture that Turkish politics witnessed in the 2002 elections can indeed be traced back to another "earthquake/tsunami", the 1980 military coup when the then-existing parties were all banned. When the elections were held in 1983, the Turkish political arena had taken a new course with entirely new agents. Advocating a hybrid program combining the elements of liberal and conservative discourses that best fitted the needs of a country that had left behind its long established tradition of import substitution, Turgut Özal's Motherland Party won two successive elections in the 1980s and left its imprint in the post-1980 reconstruction process. Özal's market-based conservative discourse not only opened up Turkish economy to global competition and thus fatally disturbing the political equations that had been geared to the maintenance of inwardoriented economic structures, but also heavily influenced the discourses of almost all the parties set up afterwards (Kalaycioğlu, 2002).

On the other hand, the left that had a long tradition of establishing its main discourse with reference to the allegations that the Republic was under a never-ending threat, failed to go beyond its elitist attitudes and managed to be the advocate of neither the pioneers nor the victims of globalization processes. The left, represented in the 1990s by various political parties, maintained its traditional attitude vis-à-vis the market and, with the impact of a crude statist discourse, could not voice the needs of large popular masses feeling the burdens of new economic policies. With their hesitancy against the European Union and a political attitude that eventually led to nationalism not different from that of traditional nationalist parties, they failed to gather the votes of both traditional leftist sections and the nationalist sections of the society (Açıkel, 2003; Bacik, 2004; Başkan, 2005).

The 1990s also witnessed the gradual rise of Islamist movement, managing in a variety of ways to become the voice of those sections of the society that had been victimized by the globalization processes and the new economic policies. Formulating their ideological stance as a reaction to the state-led modernization, and thus to the "institutionalization of a state-interpreted, official version of Islam" (Buğra, 2002, 189), they registered surprisingly high percentages of votes among the urban poor and the nascent bourgeoisie referred to as the "Anatolian Tigers" developing in the new centers outside İstanbul.

Another equally important characteristic of the 1990s is the inability on the part of established political traditions to formulate policies and programs that would appeal those living in the deprived south-eastern regions. As a consequence of the failure of mainstream parties, a locally strong proKurdish left-wing party received a considerable share of the votes cast in the region. As the Kurdish left oscillated between the strategy of adopting a political-democratic path and the strategy of remaining in the shadow of separatist discourse, the rift between the Turkish and Kurdish left became deeper (Açıkel, 2003, 200).

Given the apparent inability of existing parties to deal with the 2001 crisis and corruption, the 2002 elections took place at a time when the public was in search of novel political ideas. The results, given in Table 1 alongside the 2007 elections, testified to the opening up of a new era for Turkish politics with new political parties and agents. In our attempt to reveal the local determinants of party votes, we analyze in this paper four of these 


\begin{tabular}{lccccccccc}
\hline & AKP & CHP & DYP & MHP & GP & DEHAP & Independents & Other \\
\hline 2002 elections & & & & & & & & & \\
\hline - Percentage of votes & 34.3 & 19.4 & 9.6 & 8.3 & 7.2 & 6.2 & -1.0 & 14.0 \\
\hline - Seats in Parliament & 363 & 179 & - & - & - & - & & - \\
\hline 2007 elections & & & & & & & & \\
\hline - Percentage of votes & 46.5 & 20.8 & 5.4 & 14.3 & 3.0 & - & -2 & 4.8 \\
\hline - Seats in Parliament & 341 & 112 & - & 71 & - & - & 26 & - \\
\hline
\end{tabular}

Table 1. Party votes in 2002 and 2007 elections (TurkStat, 2002 and 2007 election results) parties: AKP, CHP, MHP and DEHAP (represented in the 2007 elections by independent candidates) and ignore DYP and GP, not only because they lost considerable ground from 2002 to 2007 but also they ceased to be important agents in current Turkish politics.

The main characteristics of the parties analyzed herein can be summarized briefly as follows:

\section{AKP- Justice and Development Party}

Following the closure by the Constitutional Court of a series of Islamist parties that had been set up since the 1970s and most importantly the ultimatum given by the military in 1997 to the coalition government, Justice and Development Party was set up in 2001 by the relatively young and moderate cadres of the Islamist movement of the 1990s. Although most of the principles of the new party were borrowed from the previous Islamist movements, the AKP leadership carefully dissociated themselves from the previous hard-liner tradition and adopted a pragmatist attitude and "a problem-solving approach which [had] grown out of the local government experiences of the leadership cadre" (Doğan, 2005, 430). Breaking with the long-established anti-European sentiment of traditional Islam and defining themselves as "conservative democrat", they adopted a conservative attitude in the social arena and a liberal attitude towards the market (Coşar and Özman, 2004; Özbudun, 2006). They gained widespread support from those who were discontent with the existing order, especially the lowermiddle-class state bureaucrats and the unskilled urban poor that were victimized by the waves of globalization and the small and medium sized traders and manufacturers especially in the rapidly developing provincial towns of Anatolia (İnsel, 2003). Given the obvious Islamist background of their leaders and the newly adopted notion of conservative-liberalism, some regard AKP as a "post-Islamist movement" (Dağ1, 2005). The party came to power in the 2002 elections at a time when the parties ruling Turkey were incapable of dealing with the 2001 crisis and "enmeshed by a web of corruption and incompetence" (Hale, 2005, 304).

\section{CHP- Republican People's Party}

Established in the 1920s by the Republican elite, CHP is the oldest and the largest centre-left party in Turkey. Advocating a radical and militant interpretation of the principles laid down in the early Republican period, among which secularism, populism and statism are the most important ones, the party experienced its heyday in the 1977 elections when it received more than $40 \%$ of votes. Failing to adapt itself to the changing circumstances of the 1980s and 1990s, CHP lost its traditional working class electoral base and offered very little to the large masses mobilized by the Islamic movement of the 1990s. As the crisis of the centre-left became chronic, the party oscillated between traditional statism, populism and neo-liberalism (Açıel, 2003), but in no case gave up defending a very 
orthodox and vulgar version of secularism, thus aiming to be the voice of the discontents of Islamic resurgence. Representing high elitism in Turkish political life (Bacik, 2004), CHP had its worst days in 1999 when it failed to pass the $10 \%$ national threshold and remained outside the parliament for the first time in its history. Especially after the 2001 crisis CHP increasingly came to defend a nationalistic discourse, manifesting itself in an irresolute attitude towards the EU.

\section{MHP- Nationalist Action Party}

MHP is an ultra nationalist party regarded by many as a pan-Turkist party "modeled on Russian pan-Slavism and emphasizing the unity of Turkic peoples throughout the Middle East and Central Asia" (Secor, $2001,540)$. Under the cold-war conditions of the 1970s the party became the audacious voice of anti-communist sentiments, with a strong rural background. Its supporters took active part in the street fights and were held responsible for the killings of many left-wing figures in the late 1970s. MHP adapted itself to the changing circumstances of the post-cold war world by replacing its anti-communist ideology with one based on a militant hostility against the European Union and the Kurdish separatist movement in the Southeast. After the death of its legendary chairman Alpaslan Türkeş in 1997, the party leadership took a decisive turn and tried hard to get rid of the street-gang and rural image of the party. In the 1999 elections the party became the second party for the first time in its history, managing to receive a considerable support among the urban electorate (Çınar and Arıkan, 2002) especially in cities attracting Kurdish migrants. With the rise of $\mathrm{AKP}$, however, the party lost ground and failed to pass the $10 \%$ threshold in the 2002 elections, largely due to its "ambivalent and inconsistent position vis- $a$-vis the conservative Islamic electorate" (Açıkel, 2003, 197).

\section{DEHAP- People's Democracy Party}

DEHAP is a pro-Kurdish party exceptionally strong in the south-eastern regions of Turkey, the traditional Kurdish area. Although the origins of the Kurdish problem and the underdevelopment of the region date back to the early Republican period and even to the Ottoman Empire, the rise of a political movement claiming to represent the Kurdish minority must be seen as a direct consequence of mounting tension and armed conflict between the government forces and the separatist PKK since the late 1980s. As the party leadership never set a distance between the party and the PKK, some regard DEHAP as "the political outlet of PKK" (Yavuz and Özcan, 2006). With the growing Kurdish nationalism, DEHAP (and a number of other parties set up before and after it, after Constitutional Court had either closed or threatened to close political parties based on ethnicity) emerged out of the obvious failure in the southeast region of the parties representing the established traditions in Turkish politics. Although it found some but limited support among the Kurdish migrants in metropolitan areas, DEHAP remained largely as a regional party, solely voicing the identity of Kurds in the region and failing to draw up a general program for the wider electorate. Managing to become the first party in 12 provinces of the region in 2002 elections, DEHAP's dominance in the region is still largely unchallenged.

The dependent variables used in both OLS and GWR models -percentage of votes received by these four parties in districts in the 2002 elections- are shown in Figure 1 by quintiles. As the maps make it clear the votes of the 


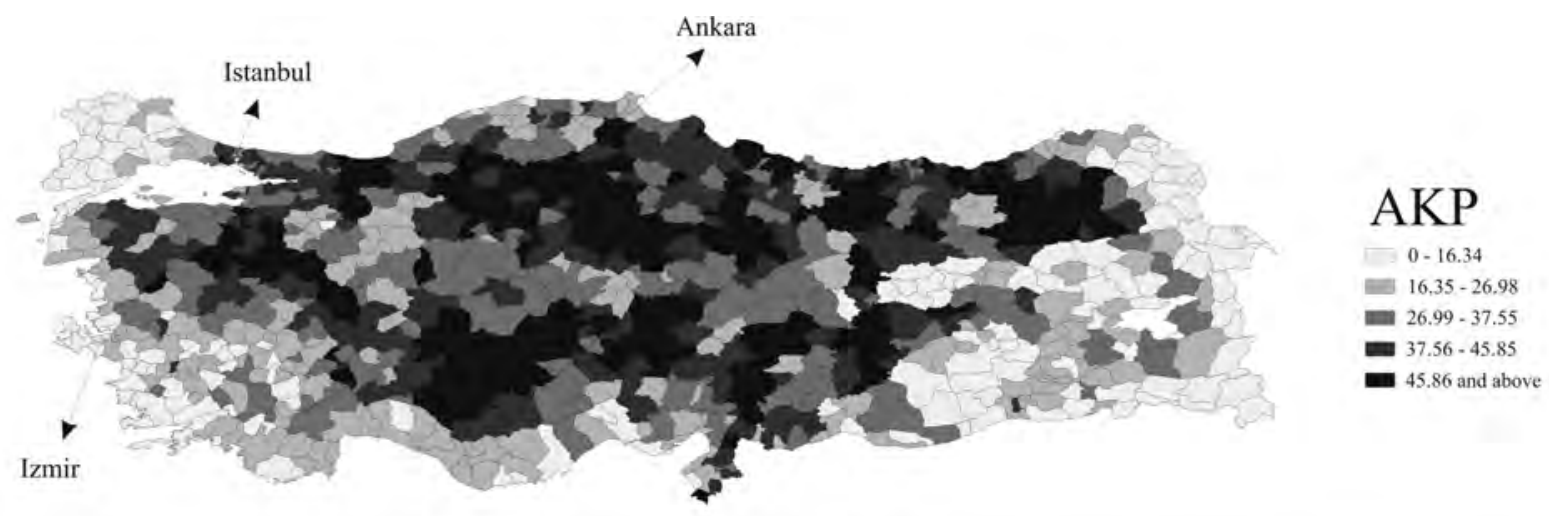

$\mathrm{CHP}$

$0-7.21$

틀 $7.22-12.09$

- $12.10-17.94$

=17.95-25.76

- 25.77 and above
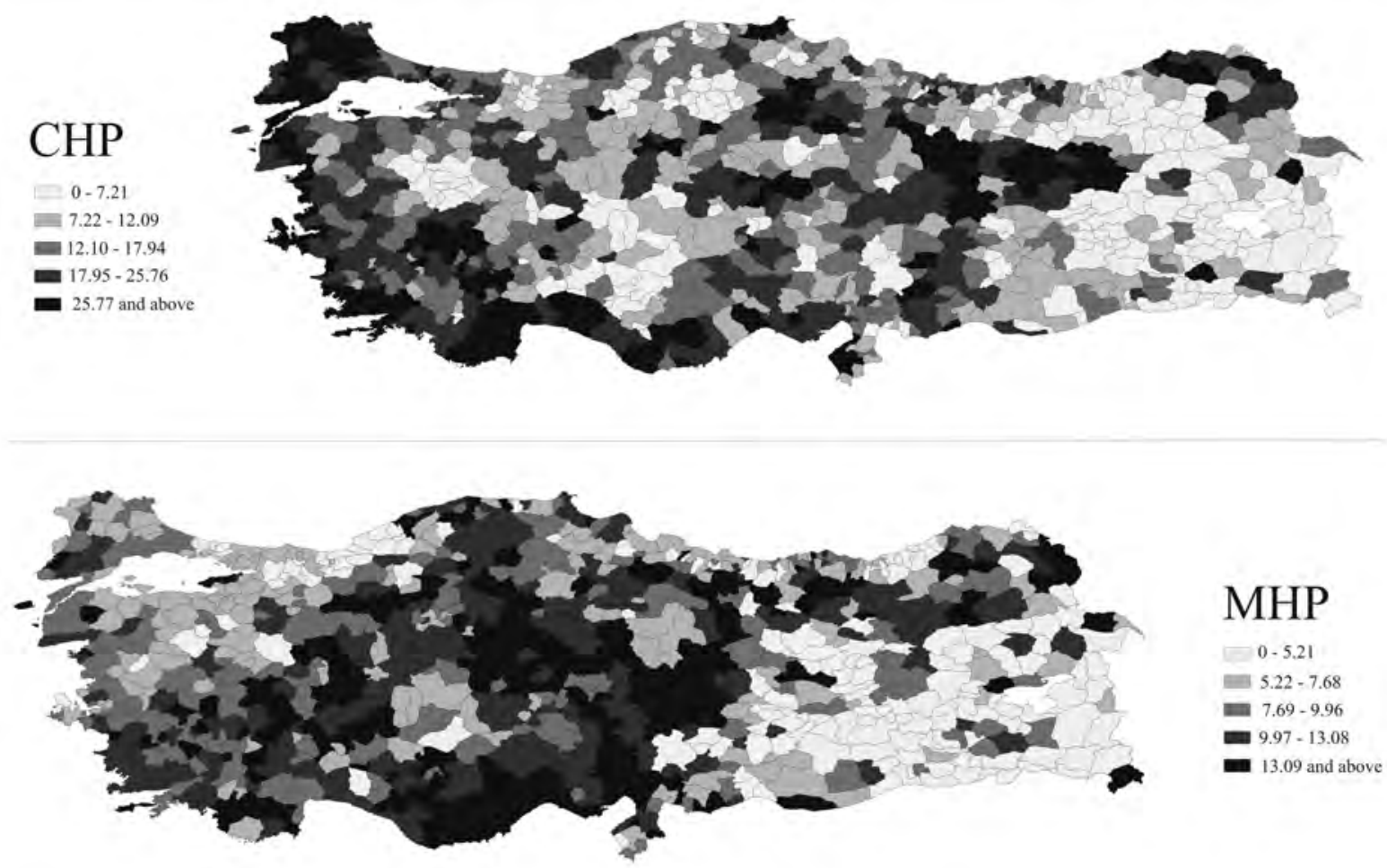

DEHAP

$0-0.97$
$=0.98-1.37$
$=1.38-2.05$
$=2.06-5.66$
$=5.67$ and above

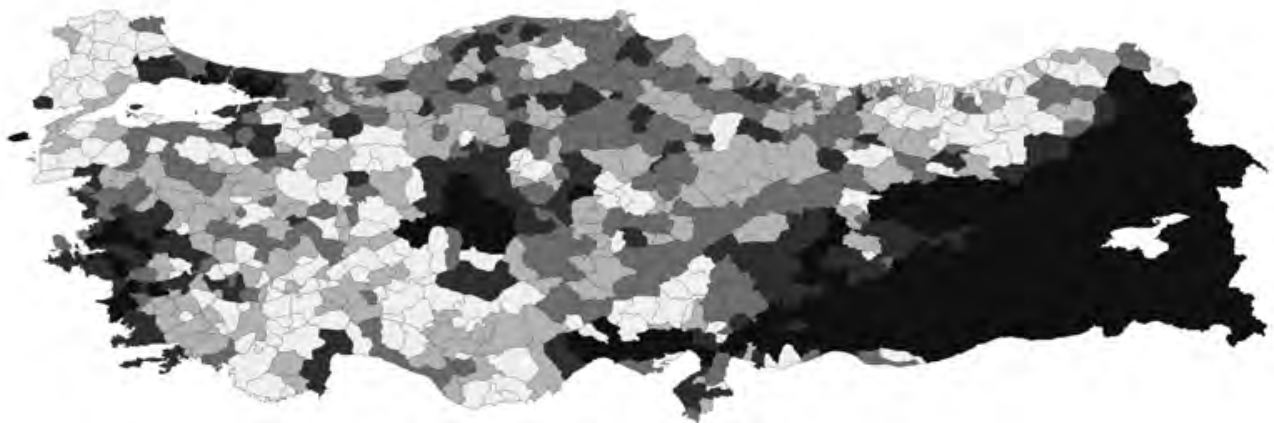

Figure 1. Spatial distribution of party votes in 2002 elections by quintile ranges. four parties tend in varying degrees to concentrate in particular regions: $\mathrm{AKP}$ votes in a strip running parallel to the north coast, $\mathrm{CHP}$ votes in western provinces, MHP parts of central Turkey and south coast and DEHAP in the east and southeast. The map for AKP also shows the three 

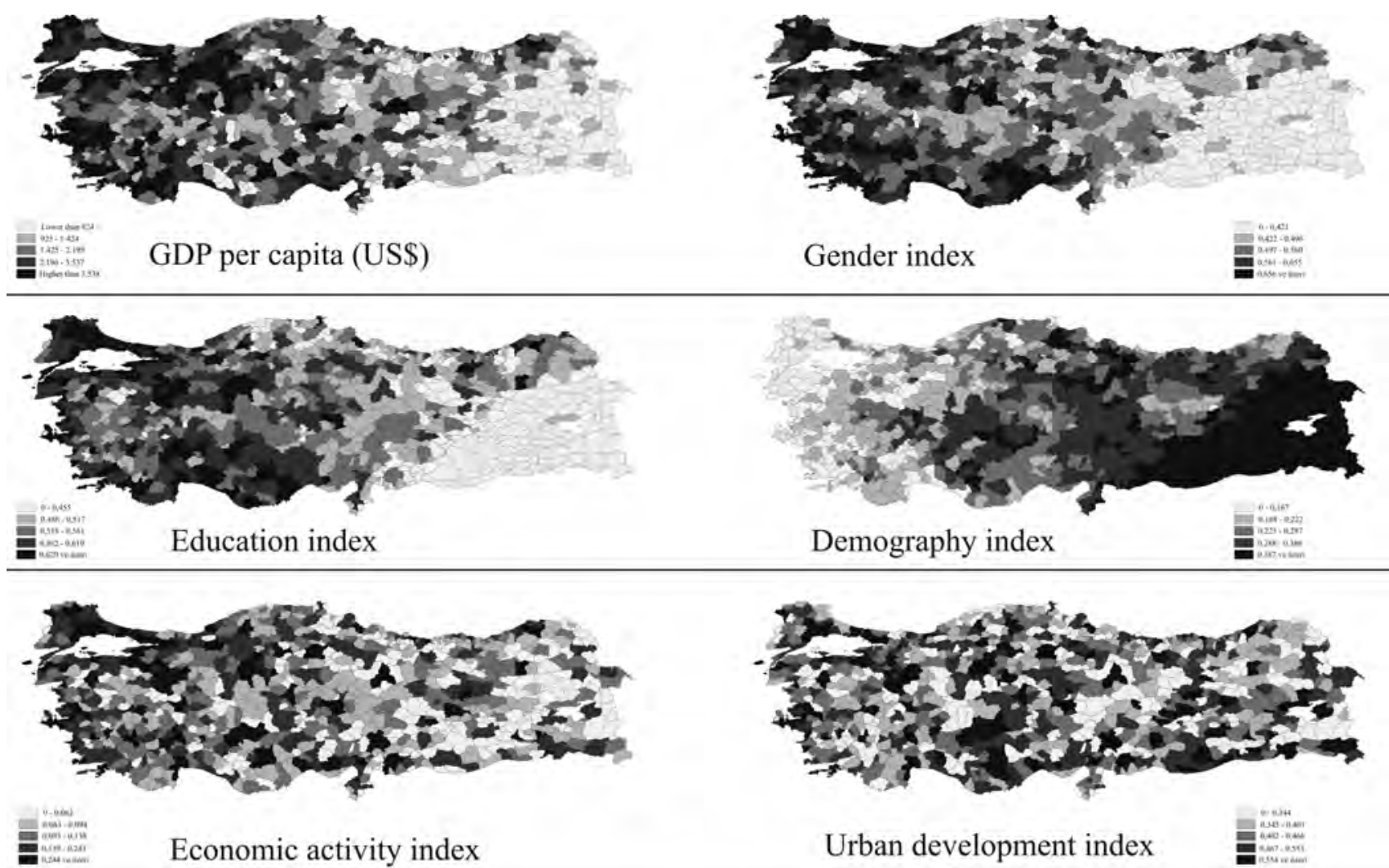

Economic activity index

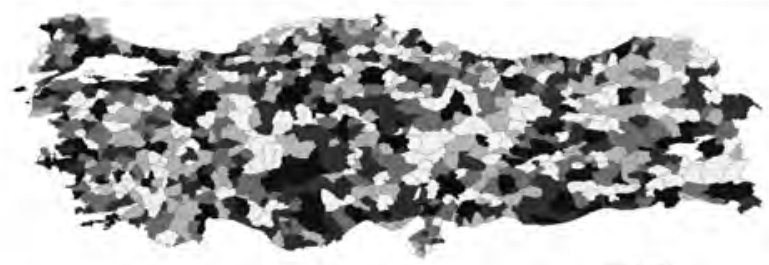

Urban development index

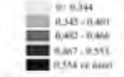

Figure 1. Spatial distribution of independent variables by quintile ranges. largest metropolitan areas of Turkey (İstanbul, Ankara and İzmir) where nearly one thirds of the electorate live. As our main concern in this paper is to reveal the reasons behind the uneven pattern of voting, we now turn to the discussion of our OLS model and introduce the independent variables.

\section{DATA and OLS}

As we discussed in the preceding section the dependent variables we use in our analysis are the percentages of votes received by the four parties in the 2002 elections in districts. The dataset we used for independent variables consists of the results of the 2000 population census for 923 districts, except the gross domestic product (GDP) variable calculated by the Turkish Statistical Institute (TURKSTAT) through national income studies and household consumption and income surveys. We used six independent variables to explain the district-wise variability of party votes. Instead of using single indicators we produced composite indices comprising a multitude of variables, except once again for the GDP variable. The spatial distribution of the six independent variables is given in Figure 2.

We attempt to explain local variations in party votes with the help of following variables:

(1) GDP (top left map in Figure 2) Per capita gross domestic product in districts in US dollars. This is the figure calculated by TURKSAT firstly in 1996 through a production-based methodology. This figure was updated later for the year 2000. As is clear on the map, the distribution of the GDP variable reproduces the well-known picture that also becomes visible in many other variables: The dichotomy between the affluent west and the 
4. While calculating the indices we used for the OLS and GWR models, we normalised the variables using the simple formula $\left(\mathrm{x}_{\mathrm{i}}-\mathrm{x}_{\min }\right) /\left(\mathrm{x}_{\max }-\mathrm{x}_{\min }\right)$, where $\mathrm{x}_{\mathrm{i}}$ represents the value of the indicator in question in district " $\mathrm{i}$ " while $\mathrm{x}_{\max }$ and $\mathrm{x}_{\min }$ are respectively the maximum and minimum values of the same indicator in Turkey. We then added these normalised values and simply divided the sum by the number of indicators, without assigning any weight to the indicators. Because of this calculation method all the indices we developed have a value between 0 and 1. deprived east, where the districts in the centre represent an in-between case.

(2) Gender index (top right map in Figure 2) The gender index we have developed to explain the local variability in party votes is comprised of two indicators (4): Female literacy rate and female participation in nonagricultural labor force. While the overall literacy rate in 2000 among the population aged $6+$ is $87.3 \%$, it drops to $80.6 \%$ in the case of females. It is interesting to see that female literacy rate exhibits a striking variability among the districts with a maximum of $96.3 \%$ and a minimum of $30.1 \%$.

The second indicator included in the gender index -female participation in non-agricultural workforce- in Turkey has been exceptionally low and changed very slowly over the years. In the year 2000, out of a total of 13.4 million people working in non-agricultural sectors, only $11.7 \%$ are women. With a rapid increase in working age population coinciding with a structural transformation away from labor-intensive agriculture towards industry and services, women have found it increasingly difficult to find a place for themselves in the urban labor market due to low level of educational attainment (World Bank, 2006).

The higher levels of the gender index denote the cases where women are better educated and more active in non-agricultural sectors. Close-to-zero levels of the index, therefore, refer to the opposite cases. The top right map in Figure 2 shows that this index is high western districts along the Aegean Sea and the Mediterranean. The map also reveals once again the harsh conditions faced by women in the eastern and south-eastern regions.

(3) Education index (middle left map in Figure 2) Having introduced the basic concepts related to the design of the indices, we can now move faster in our discussion of the independent variables. The education index comprises adult literacy rate, the percentage of university graduates and the difference between male and female literacy rates. The higher the education index, the more educated the settlement in question is. On the contrary, the low levels of the education index refer to the cases where the population is less educated and there is a considerable gap between male and female literacy rates. The relevant map in Figure-2 depicts a picture very similar to previous maps and reveals the huge gap between western and eastern regions in terms of education-related variables.

(4) Demography index (middle right map in Figure 2) The demography index is composed of three variables: Average household size, child woman ratio as a measure of recent fertility (the number of children under age 5 per 1000 women of reproductive age) and the dependency ratio (the ratio of dependent population, i.e. population aged 0-15 and $65+$, to the economically active population, i.e. population aged 15-64). The low levels of demography index refer to those settlements where the fertility rate is low, average household size is small, i.e. to those where population has become more or less stabilized. Where the demography index is high, the percentage of young population and the rate of fertility are high. Viewed in terms of the famous demographic transition theory, the settlements with lower values of demography index are those that are about to complete their demographic transition process, while those with high values are in the earlier stages of the demographic transition. The map reproduces, in the case of demographic variables, the well-known general pattern of regional inequalities in Turkey (Işık and Pınarcığlu, 2006b). 
(5) Economic activity index (bottom left map in Figure 2) This index designed to measure the diversity of economic activities in a given settlement includes four variables: The share in total working population of those working (a) as entrepreneurs and high level directors; (b) in manufacturing industry; (c) in agriculture, and (d) in finance, insurance and real-estate sector. This index is actually designed to understand the part played by agriculture and non-agricultural activities in a given settlement. The higher the economic activity index, the lower the level of agriculture and the higher the percentage of those in non-agricultural activities. It is interesting to note that the map in Figure $\mathbf{2}$ does not have an easily discernible pattern. In addition to a milder east-west differentiation compared to previous maps, province centers do emerge as important poles of economic activity in each case.

(6) Urban development index (bottom right map in Figure 2) Designed to measure the pace of urbanization in a given settlement, urban development index is composed of two indicators: The percentage of urban population and the annual growth rate of urban population. The higher the urban development index in a given settlement, the more urbanized the district and/or the higher the population growth is.

The results of the ordinary least squares regression analysis made with the above variables are given in Table 2 which also contains some information about the results of the GWR analysis to be discussed in the following section. As can be seen in the Table, the explanatory power of the

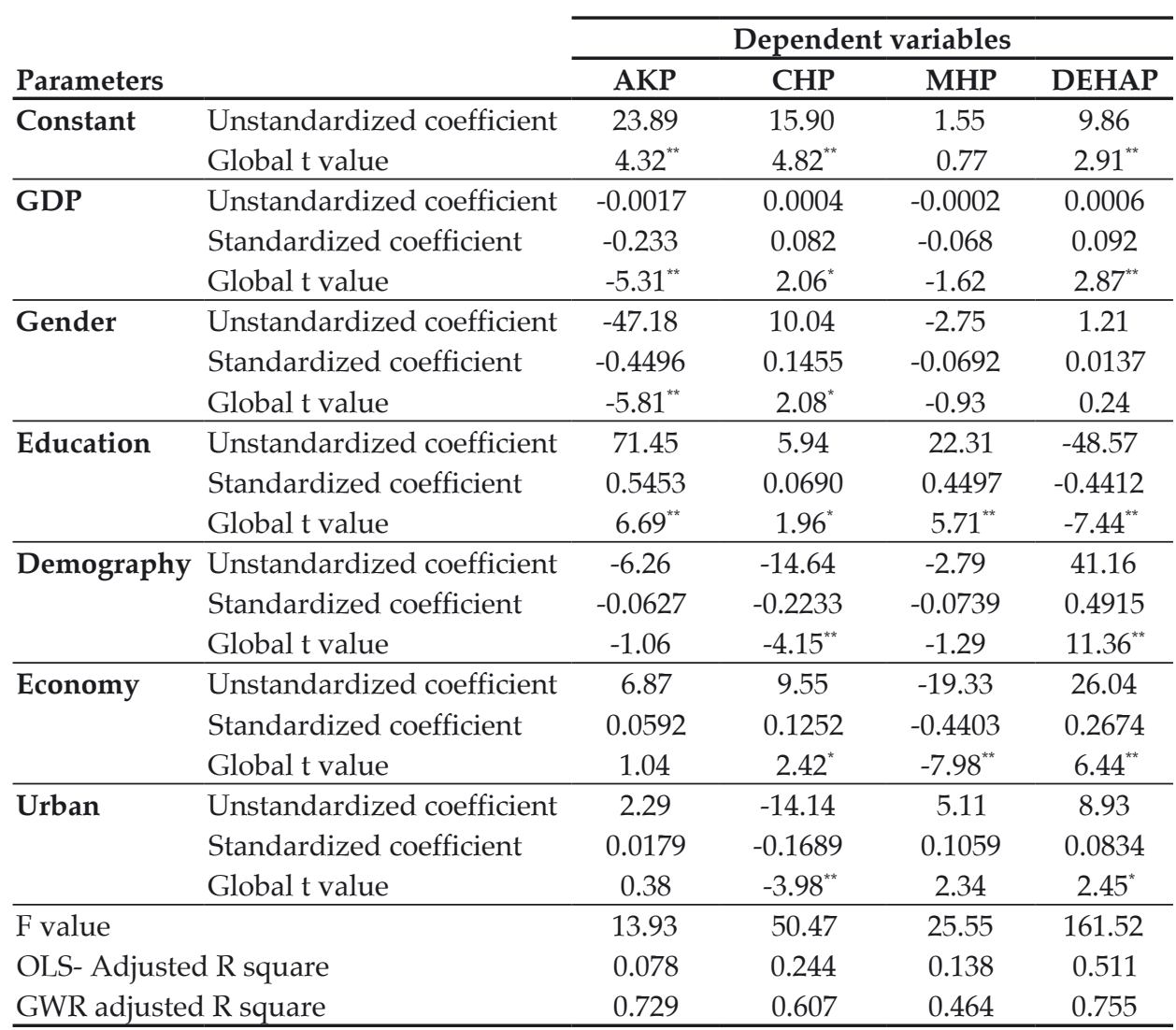

\footnotetext{
Number of observations: 923

* Significant at $p<=0.05$

** Significant at $\mathrm{p}<=0.01$
} 
independent variables is usually very low, except for DEHAP for which $R^{2}$ is the highest $(0.51)$. For other parties, the $R^{2}$ values vary between 0.08 for AKP and 0.24 for CHP and 0.14 for MHP. In general, however, the OLS model does not seem to be capable of explaining the global reasons behind the different percentages of votes received by parties.

There are, however, some details concerning the relationship between particular party votes and some variables. It is, for instance, interesting to note that there exists a positive and highly significant relationship between $\mathrm{AKP}$ votes and education, while the relationship is reversed in the case of GDP and the gender index. Hence the higher the level of education and the lower the income and women's participation in economic life, ceteris paribus, the higher the percentage of AKP votes in a given settlement. Restricting our observations only to those relations that are statistically highly significant, we see that $\mathrm{CHP}$ votes are negatively related with demography and urban indices. Of the relationships revealed by the OLS analysis, the one that is the easiest to interpret is the case of DEHAP, in which the coefficient of determination is much higher than that of other parties. DEHAP votes are positively correlated with the demography index, meaning that this party finds its popular support in areas where fertility is high. On the other hand, there exists a highly significant negative relationship between DEHAP and education referring to the fact that DEHAP tends to be stronger, ceteris paribus, where the level of education is low. In the next section we analyze, with the aid of GWR, how these relations change from one district to another and find out that there are numerous differences that remain hidden in the global analysis.

\section{GWR Model}

Allowing the parameters of a regression equation to chance locally, geographically weighted regression technique is an effort to open up room for spatial heterogeneity in geographical research. Based on the understanding that the very same cause may lead to a different effect in a different setting, GWR acknowledges the fact that the global (necessary) relations unearthed in the OLS model may not work in a particular locality where spatially changing (contingent) impacts of independent variables may lead to an entirely different outcome. It is thus the contextdependent nature of social interaction that GWR takes into account. As a technique of spatial analysis GWR was initially formulated and developed by Fotheringham, Brundson and Charlton (see Brundson, Fotheringham and Charlton, 1996, 1998, 1999 and 2000). Since then it has become one of the most widely used techniques of spatial econometrics with increasing applications in a variety of fields including regional studies (Bivand and Brunstad, 2002), environmental studies (Platt, 2004), political geography (Calvo and Escolar, 2003) and demography (Işık and Pınarcıoğlu, 2006b).

In the GWR analysis, one of the observations is selected as the reference point and all other observations are weighted according to a decreasing function of distance from the reference. Having calculated the parameters of estimation for the reference point, these calculations are repeated for all observations in the dataset (4). The result is a series of mappable coefficients (including regression coefficients, $t$-values and coefficients of determination) showing the various aspects of the local relation between dependent and independent variables. This, indeed, refers to the most difficult task faced by the analysts using GWR- the difficulty of interpreting the results as there are many outputs of the model. In our case for instance, assuming that we wish to map regression coefficients, t-values 
6. In this study we used GWR 3.0 software developed by Fotheringham and his coworkers.

7. The analysis we carried out in the case of Ankara for the 2002 elections provides support to this result. The results showed that AKP was stronger in the northern parts where the level of education is low. On the contrary, CHP did considerably better in the southern parts of the city where the better-off live. and coefficients of determination and considering that we have used 4 independent and 6 dependent variables, this means that $3 \times 4 \times 6=72$ maps can be produced for 923 districts. In this study we preferred, following Farrow et al. (2005), to interpret the results with the help of local t-values showing the significance of the relationship between dependent and independent variables (6). Furthermore, instead of trying to explain all the variables for all political parties, we preferred to carry out a variable-wise analysis for a number of, rather than all, variables which seemed to be of importance for most of the parties.

Before discussing the GWR results, we should add a few words as to the contribution it has made to our understanding the relationship between party votes and independent variables. In Table 2 where the OLS results are summarized the contribution of the GWR can easily be seen. The results obtained indicate that GWR significantly improved the OLS results with $\mathrm{R}^{2}$ values increasing in every case, the highest being the case of AKP from 0.08 to a fairly well level of 0.73 .

The first variable we wish to consider is the education index. Figure 3 shows the relationship between education and party votes at the local level. The most important point that becomes visible in Figure 3 is the relationship between AKP votes and the education index. Although the analysis at the national level revealed the existence of a highly significant positive relationship between AKP votes and the education index, the GWR results make it clear that this relationship is highly variable in space. Not only does the significance of the relationship between AKP and education change considerably from one district to another, but also the direction of this relationship is reversed in many cases. It may be observed from the top left map in Figure 3 that this global relationship between AKP and education holds true only for a limited number of districts clustered into four groups in different parts of the country. These are the districts where AKP has found itself a popular base among the better educated. There are, however, major and very interesting exceptions to this relationship. The GWR analysis reveals that there are a number of districts where there is a reversed relationship between AKP and the educated. In a wide area stretching from Istanbul to Izmir in the west and covering most of Ankara in the centre, AKP has an entirely different relationship between the education index. In all these districts including the three largest metropolitan areas of Turkey, there is a significant negative relationship between AKP votes and the level of education, meaning that the higher the level of education, the lower the AKP votes. Put conversely, the lower the level of education, the higher the AKP votes in metropolitan areas, a finding that refers to the popularity of AKP among the urban poor.

The map concerning the local relationship between CHP and the education index (second from top in Figure 3) tells an entirely different story. This map is almost a flawless negative of the one for AKP. The significant positive correlation between CHP and education at the global level seems to be valid only for those areas where education is negatively correlated with AKP votes. In metropolitan areas comprising a major portion of the votes cast in Turkey, AKP and CHP have constituted different relationships between the educated- $\mathrm{CHP}$ doing well among the better educated and AKP performing better among the less educated (7). As far as the largest metropolitan areas are concerned, this means that the two leading parties have different social bases. Of the other maps in Figure 3, the one that deserves attention is that for DEHAP (bottom map). The highly significant 


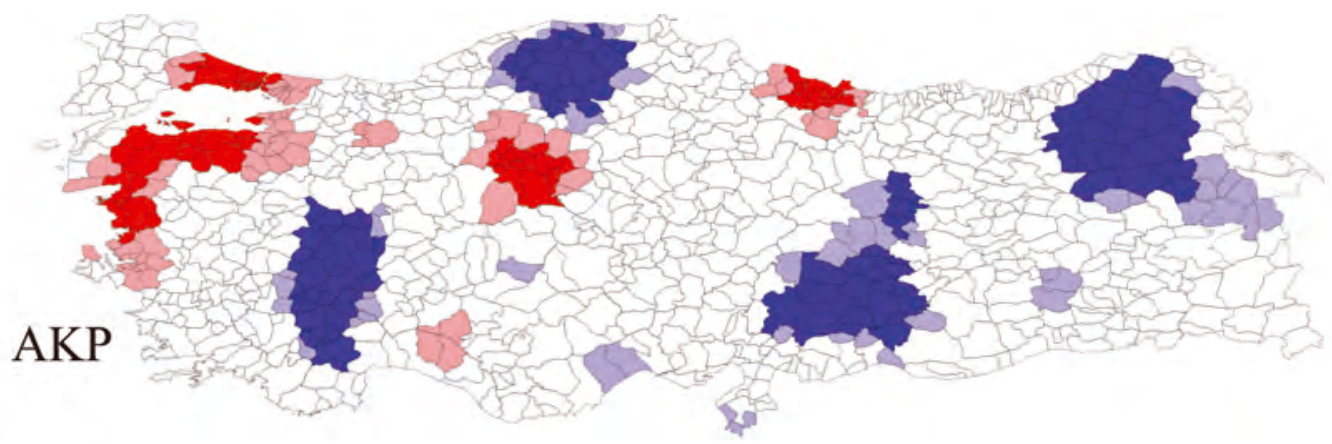

\section{CHP}
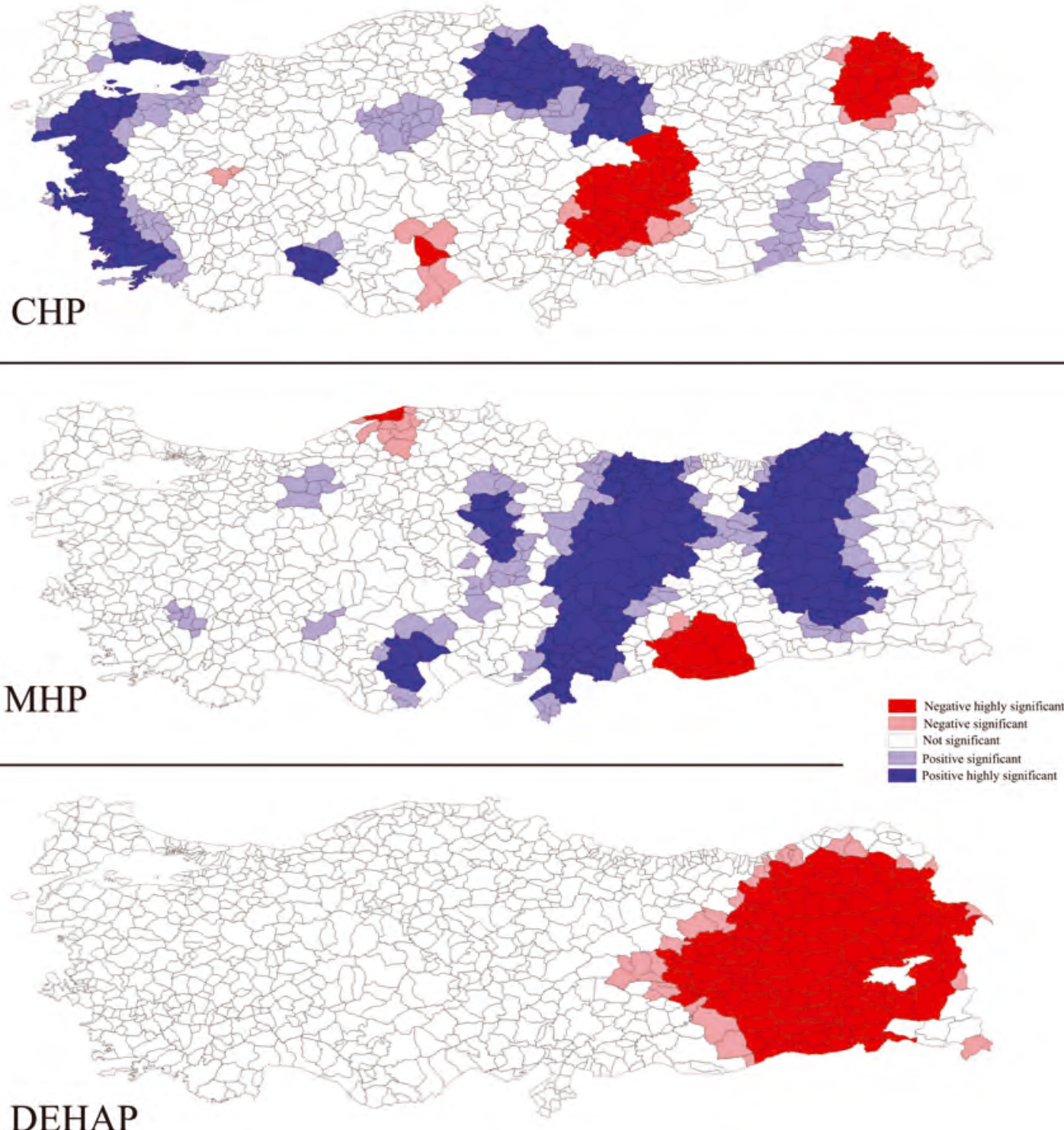

Figure 3. Local relation between education index and party performances.

negative relationship discovered in the global analysis is valid only for the eastern and south-eastern districts where DEHAP has a strong support and where the level of education is considerably low compared to the rest of Turkey. This may be regarded as an indication of the fact that DEHAP owes, at least part of its success in the region, to the low levels of education 


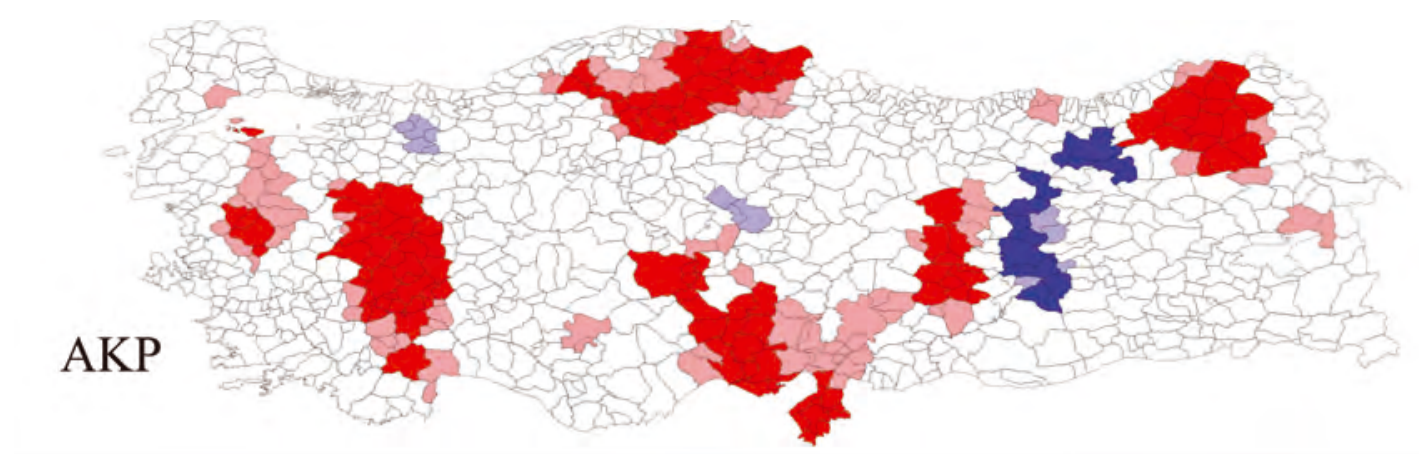

CHP
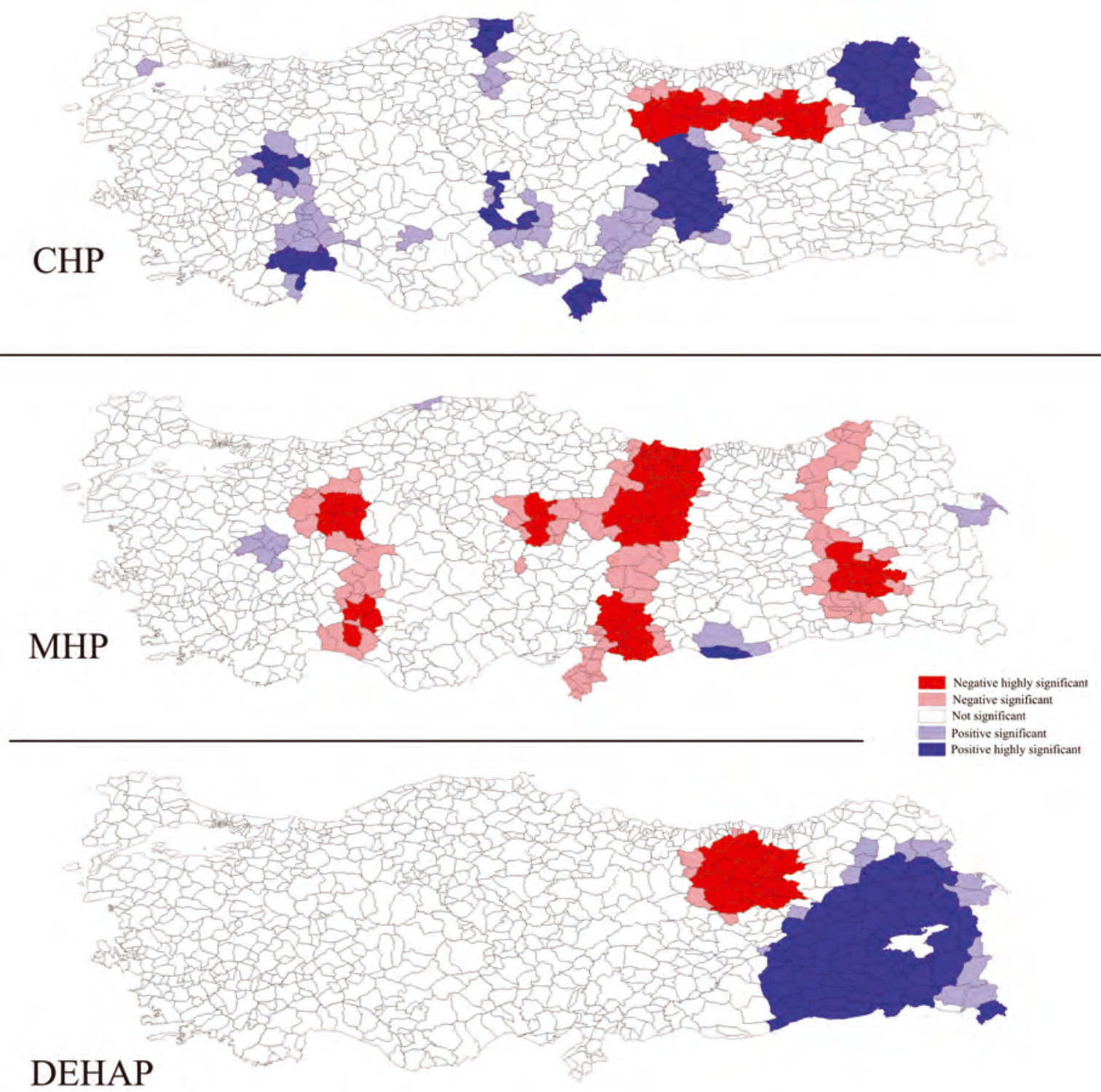

Figure 4. Local relation between gender prevailing in the region. In no other part of Turkey is there a significant index and party performances. relationship between the level of education and DEHAP votes.

The set of relations between what we referred to as the gender index and the party votes is shown in maps of Figure 4. Starting from the top, in 
the case of AKP there is a highly significant negative correlation between women's position, meaning that AKP tends to perform better in districts where the gender index is lower. As the map shows, the districts where this correlation is valid seem to have clustered in four areas: One each in the northeast, mid-north, mid-west and a larger area in the south. The global relation revealed in the OLS analysis is true only for these districts. Except for a few districts in the mid-east region, there exists no significant positive relationship between AKP and women's social position. In the case of CHP, the significant positive relationship with the gender index manifests itself in four clustered areas, which are more or less the same as those where AKP has a strong negative relationship. This means that in districts where there is a strong negative correlation between AKP votes and women's position, there is an opposite relationship for CHP. These findings may be interpreted, with some degree of caution, as another evidence to the fact that both parties have different popular bases. In a given district a particular factor that leads to a rise in AKP votes leads directly to a decline in CHP votes. The opposite of this argument is also valid: what causes $\mathrm{CHP}$ votes to increase in particular area leads to a decline in AKP votes in that area.

Looking briefly at the correlation between gender index and other parties, the not-too-significant negative relationship between MHP and the gender index at the national level turns into highly significant negative one in three narrow strips extending from north to south almost without any interruption. One can note in Figure 1 that of these three strips the one in the middle covers districts where MHP has done particularly well. And finally DEHAP's more or less neutral relation at the national level with the gender index turns into a strong positive one in the southeast where it has the majority of its voters.

For the local relationships between the economic activity index and party performances (Figure 5), we could say that the relationship between AKP and CHP votes detected in the case of two previous variables holds true for this variable as well. In areas where the economic activity index asserts a negative impact on AKP votes (in other words, where the weight of agriculture and AKP votes change in the same direction), $\mathrm{CHP}$ has the opposite relationship, or vice versa. Even a cursory examination of the maps on the top row of Figure 5 could testify to this fact. On the other hand, MHP has a significant negative relationship with the economy index in a large proportion of districts in Central Anatolia, which means that the share of MHP votes tends to rise as the share of agriculture rises. And DEHAP displays once again its character as a truly regional party, with the highly significant positive impacts of the economy index in the provinces of the east and southeast.

In Figure 6 there are local relations between some parties and a number of selected variables. The two maps on top show the local relationship between AKP and CHP votes and GDP per capita. Although AKP is negatively and CHP is positively correlated at the global level with GDP, there are many exceptions where a reverse relationship holds. Three of the four clusters where AKP votes are positively correlated with GDP contrary to the national trend (from left to right Denizli, Kayseri and Gaziantep provinces) are those provinces referred to as "Anatolian Tigers" that showed unprecedented development during the 1980s and 1990s taking advantage of labour intensive exports in the global markets. In those places the global relationship between AKP and per capita GDP is reversed, 

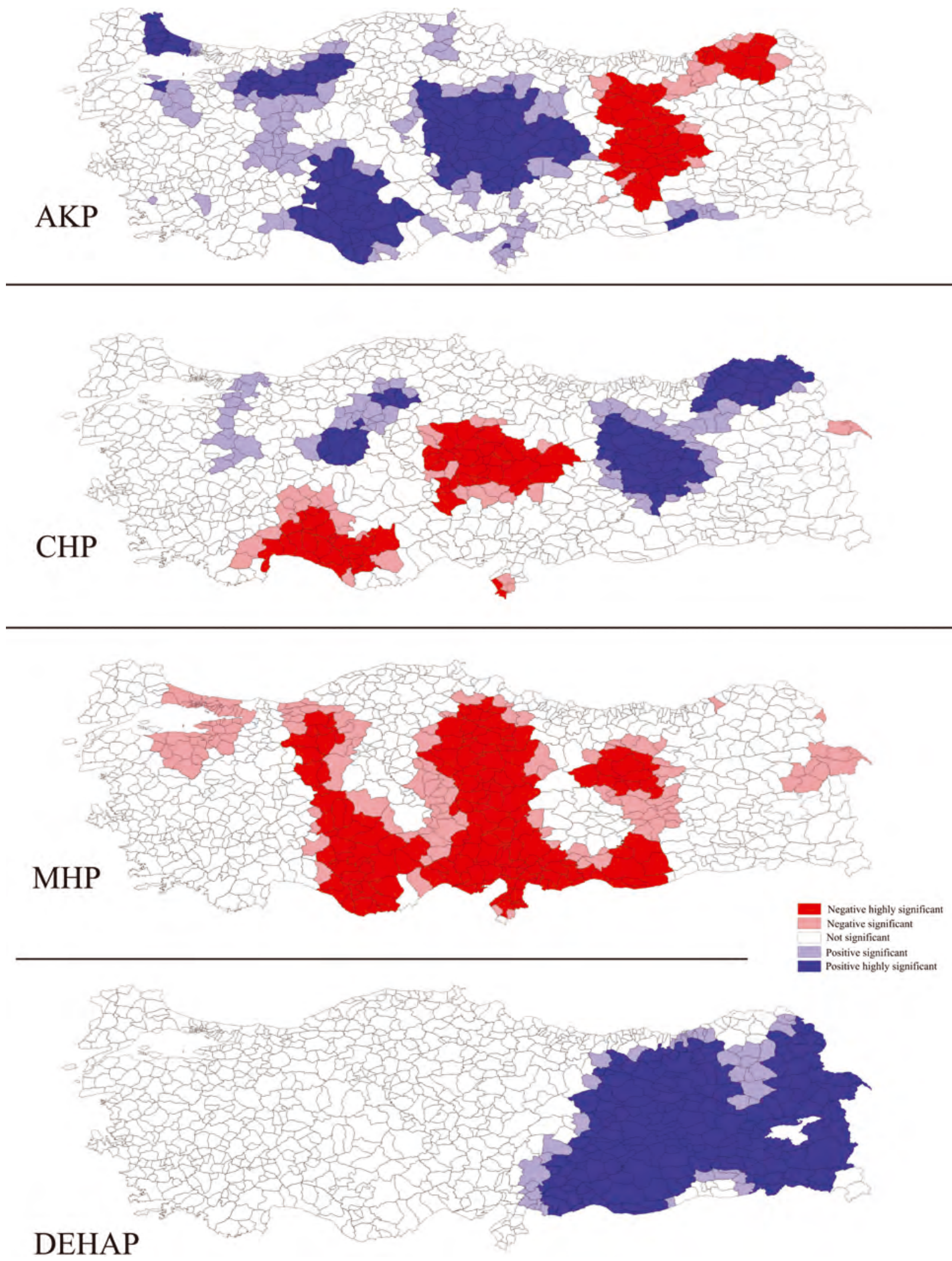

Figure 5. Local relation between economic activity index and party performances. 


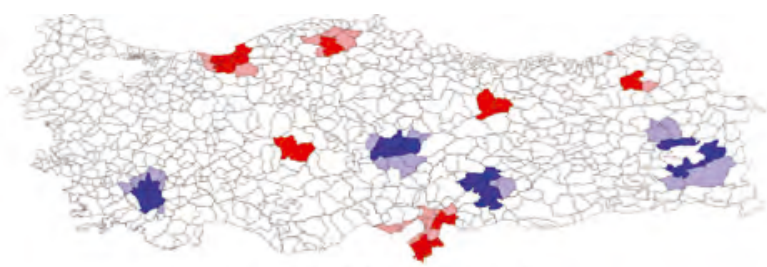

AKP and GDP per capita

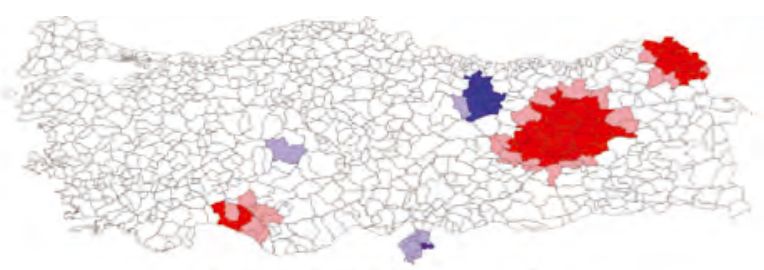

CHP and GDP per capita

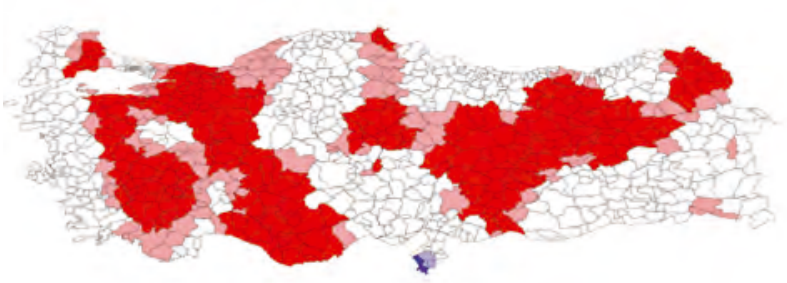

CHP and demography index

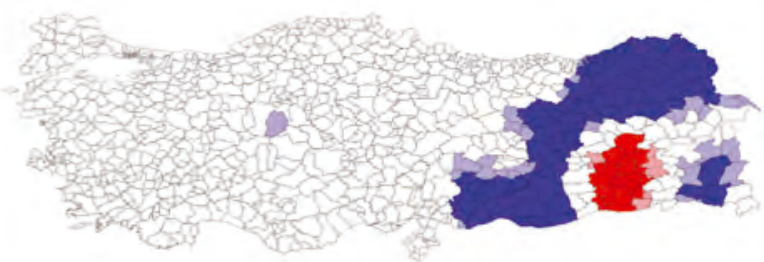

DEHAP and demography index

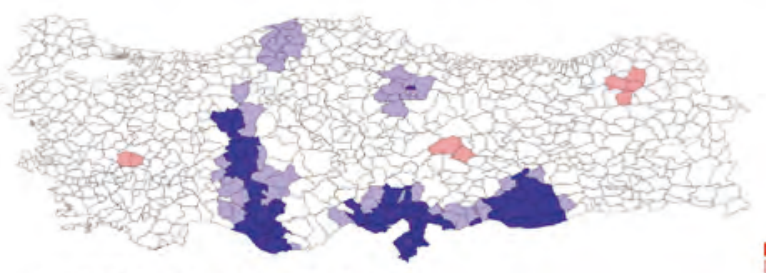

MHP and urban index

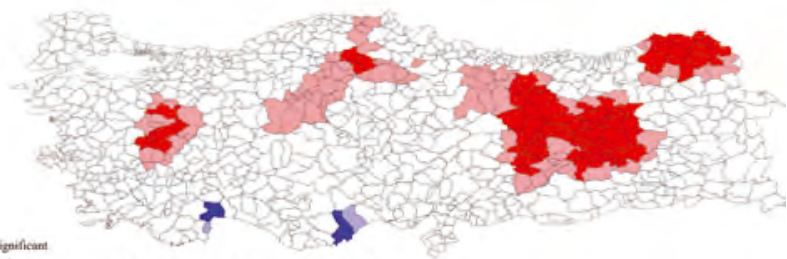

CHP and urban index
Figure 6. Local relation between party performances and selected variables. meaning that the higher the per capita income, the higher the percentage of its votes. As for CHP, two clusters of districts, one in the northeast and the other in the east, appear as areas where the national trend is reversed. In those areas, contrary to the OLS results, the lower the per capita income, the higher the percentage of the party's votes. This means, there are some dynamics at work probably peculiar to those areas strong enough to reverse the national trends. In fact, one of these dynamics may be the fact that these districts (especially those in the east) are known to be the traditional living areas of the Alevi population, who as the followers of a more heterodox understanding of Islam have historically tended to vote for CHP (Erman and Göker, 2000; Çarkoğlu, 2005).

As for the local relation between party performances and demography index, only DEHAP has a very strong positive correlation at the national level with demography-related indicators. Though different in magnitude and significance, all other parties do have positive correlation with the demography index. On the middle row of Figure $\mathbf{6}$ are the maps showing the local relation between demography index and CHP and DEHAP votes. As far as DEHAP is concerned, one could easily observe that this map clearly seems to have an entirely different pattern. The highly significant positive correlation that exists nationwide between DEHAP and the demography index is reversed in what is almost the geometric centre of an area where DEHAP is the strongest. In this particular zone where fertility is high and the average household size is higher than the average, in short where the demography index is high, this variable exerts negative impact on DEHAP's votes. Another interesting point is the fact that this 
core is almost like an enclave, encircled by districts where there is a strong positive relationship between DEHAP and demographic variables. The situation as to demography is entirely different for CHP (middle left map in Figure 6). The negative correlation between CHP votes and demographic variables seem to cover a very wide area. Any increase in fertility and household size seems to have a negative impact on CHP in a wide area.

In the case urban development index, there appears an interesting case for $\mathrm{CHP}$ (bottom right map in Figure 6). This variable, comprising percentage of urban population as well population growth rate, exhibits only negative correlation with CHP. According to this correlation, an increase in this index (in other words, an increase in urban population and population growth) might lead to a concomitant decline in CHP votes. It seems in the map that this negative relationship is valid especially for two areas covering north-east and some parts of eastern Anatolia. It should be noted that these areas are characterized by a considerably slow rate of population growth largely because of out-migration. The lower values of urban development index (namely low levels of urbanization and a slow and even a minus growth rate) seems to have exert a positive impact on $\mathrm{CHP}$ votes. As out-migration rises, so do $\mathrm{CHP}$ votes. This could be explained with reference to the elderly population, who choose not to migrate and who also might have a tradition of supporting CHP. As for MHP, one could easily see that the positive, but almost neutral, national relationship between its votes and urban index is highly significant in a number of districts along the south coast. It must be noted that these are the districts that witnessed a massive Kurdish migration from the south-east in recent years and where MHP found a strong electoral base among those that are discontent with this inflow of Kurdish population.

\section{CONCLUSIONS}

Analyzing the results of 2002 elections with the help of GWR technique, we tried in this paper to understand the geography of various factors that make political parties' votes differ from one region to another in a country like Turkey characterized by a high level of social and geographical inequalities. Specifically this paper analyses the reasons behind the spatial heterogeneity of voting patterns in Turkey, shedding light on the social and economic determinants of party preferences at the local level. As exemplified in several cases above, GWR is a technique capable of revealing the local relationships that may remain hidden in a global analysis. Even in cases where there is a significant national relationship between a particular party's votes and a set of variables, there are localities where some locale-specific factors may be effective upon the significance and even reverse the direction of this relationship.

The following conclusions deserve to be reemphasized in connection with the GWR analysis:

\section{Sharp contrast between AKP and CHP in terms of local determinants:}

Probably the most important conclusion to be drawn from the above analysis is the finding that AKP and CHP, the two leading parties in Turkish political arena, seem to have almost entirely opposite relations with independent variables. In a given district a particular factor leading to a rise in AKP votes leads directly to a decline in CHP votes. This cleavage between AKP and CHP is reminiscent of the well-known tension between the secular, urban and West-oriented "centre" and religious, 
agricultural and traditional "periphery", a tension which for Mardin (1973) has been the distinguishing character of Turkish politics since the foundation of the Republic and which for many is still the most salient axis of political divisions in Turkey (Sayarı, 1978; Özbudun, 1981; Tachau, 1984; Kalaycıŏlu, 1994).

\section{The poor neighborhoods of rural migrants in metropolitan areas- new areas of the periphery:}

In its classical formulation by Mardin (1973) the "periphery", equated mainly with peasantry, small farmers and artisans, would have a tendency to vote for conservative parties and it was believed that right-wing votes would rise in line with the rural character of a settlement (Çarkoğlu and Hinnich, 2006). The GWR analysis, however, makes it clear that this is true only for MHP in central parts of the country. On the other hand, this is certainly not true for AKP, which seems to represent the traditional and religious values associated with the periphery. As evidenced by the relationship between AKP votes and economy and urban indices, AKP does have a very strong popular base in urban areas. This paradox can be explained with reference to the peculiarities of urbanization process that Turkey has undergone in the last four decades. The influx of rural migrants into urban areas has not brought with itself an atomistic and individualistic urban culture as suggested by the classical theories of urbanization but been characterized by the predominance of various community-type relations organized along the lines of traditional values such as religion and ethnicity (Pınarcıoğlu and Işık, 2008). It can thus be claimed that the well-known centre-periphery tension has now been transferred to urban areas in the guise of a new tension between the well-educated rich and the less-educated poor. The fact that AKP has found itself a strong popular base among the less educated in metropolitan areas must be regarded as evidence to this claim.

It must also be emphasized that the negative significant relationship between the education index and AKP votes in metropolitan areas, which we regard as the evidence of the new guise of the well-known centreperiphery tension, did remain hidden in the OLS analysis carried out at the national level. Furthermore, the GWR results testified once again to the well-known relationship between $\mathrm{CHP}$ as the party representing the centre and the well-educated segments of the population especially in metropolitan areas.

\section{AKP as the party of educated and traditional family life in the central and northern Anatolia:}

The picture that emerges in relation to AKP in metropolitan areas is somewhat reversed in other parts of the country. Although AKP has a popular base among the less-educated poor of urban areas, it seems to have either neutral or positive significant relationship with the education index in a large number of districts. In a number of clusters located in central and northern parts of Turkey AKP does have strong base among the relatively educated. However, the fact that AKP votes are negatively correlated with the gender index and positively correlated with the demography index and the fact that these relations get more significant where AKP is strong show us the conservative and Islamist face of the party. As far as its strongholds in central and northern Anatolia are concerned, AKP has a wide electoral base in places which do not give much role to women in the labor market and public sphere. AKP strongholds in central and northern Anatolia are 
settlements where women are particularly inactive in the labor market and fertility is relatively high. It can thus be conferred, albeit indirectly, that increasing education and welfare standards especially in settlements where AKP is strong has not led to the emancipation of women (Işık and Pınarcioğlu, 2006b).

\section{The rising Anatolian Tigers and AKP:}

The GWR analysis as to GDP shows us another interesting point that can account for the success of AKP. The clusters of settlements where AKP has a strong positive relationship with income consist mainly of places known as "Anatolian Tigers" that showed unprecedented success in the 1980s and 1990s venturing in the global economy. Those provinces were quick on the uptake of potentials in the globalization and the places that became the venues of entrepreneurship and gained the tag of Anatolian tigers during that period. As seen in GDP results, AKP, defending liberal economic policies, has significant positive relations with their votes and GDP in those places.

\section{CHP as the party of the urban elite and Alevi population:}

One of the most striking features of Turkish political arena has been the narrowing electoral base of social democrat parties. CHP seems to have strong popular base only among the well-educated urban groups and in areas where Alevi population live.

\section{First signs of strange bed fellows, CHP and MHP:}

$\mathrm{CHP}$, a party of a member of Socialist International and MHP, nationalist right wing party, have been traditional foes, and their popular bases have always been thought to have the completely opposite ideological and social poles. However, just after AKP took office and started to follow post-secular, multi-identity and liberal politics, those foes have gradually built up a friendship on a similar political ground in the face of Kurdish question, European Union candidacy, privatization etc. following single identity based nationalist and statist politics. As far as urban development and economic activity indices are concerned, one can see the early signs of such rapprochement in several clusters in Turkey in the 2002 elections.

\section{DEHAP- a truly regional party in every sense:}

DEHAP has the strongest positive spatial dependency in the party votes, meaning that localities where it is strong tend to be surrounded by localities having a similar characteristic. In fact, DEHAP does not seem to go beyond being a regional party of the Southeast where problem of regional disparity and Kurdish ethnic identity has translated into growing Kurdish nationalism in the last two decades. The analysis makes it clear that DEHAP has been unable to reach the Kurds living outside the traditional Kurdish region, turning into a truly regional party having very little to say to those living in other parts of the country. Another important evidence of the fact that DEHAP is a truly regional party is the finding that all of the significant relationships discovered herein, either positive or negative, are peculiar to the region, not observed in any degree in any other part of the country.

In short, such an analysis for the local determinants of party preferences shows how geography makes difference in the relationship between the voting patterns and social economic factors shedding light on the peculiar elections in 2002. Applying the same analysis to the 2007 elections when 
the AKP's success in elections actually continued with an increasing trend, garnering almost half of the votes from the populace will surely make us understand the electoral in specific, political in general transformation that Turkey has undergone in the new millennium with a strong mandate of a party with deep Islamic roots. Nevertheless, the data limitations do not let us to do so since there is no corresponding economic and social data set available for the 2007 elections.

While the country has become more and more urbanized with the influx of migrants to cities, it seems that the pivotal focus of interest of right wing parties shifted from rural areas to the less educated poor migrants living at the outskirts of the metropolitan areas. It seems clearly to be the case that AKP found itself an electoral base that is radically different from the traditional right-wing and Islamist parties: the urban poor and the nascent entrepreneurial classes in the rapidly developing provincial towns. On the other hand, the traditional popular base of social-democrat CHP, i.e. the educated urban elite, is under increasing threat from the nationalist MHP. The extent to which all these balances may be long-lasting in a country characterized by wide social and regional inequalities and high rates of social and geographical mobility will be determined not only by what is likely to happen in Turkey but also by the wider changes in the global economy of which Turkey is increasingly a part.

\section{REFERENCES}

AÇIKEL, F. (2003) Mapping the Turkish political landscape through November 2002 elections, Journal of Southern Europe and the Balkans 5(2) 185-203.

BACIK, G. (2004) The Parliamentary Election in Turkey, November 2002, Electoral Studies 23; 821-45.

BACIK, G. (2008) The parliamentary elections in Turkey, July 2007, Electoral Studies 27(2): 377-81.

BAŞKAN, F. (2005) At the crossroads of ideological divides: Cooperation between leftists and ultranationalists in Turkey, Turkish Studies 6(1) 53-69.

BIVAND, R. S. and R. J. BRUNSTAD (2002) Regional growth in Western Europe: An empirical exploration of interactions with agriculture and agricultural policy, Norwegian School of Economics and Business Administration, Discussion Paper.

BRUNSDON, C., A. S. FOTHERINGHAM, and M. CHARLTON (1996) Geographically weighted regression: A method for exploring spatial nonstationarity, Geographical Analysis 28(4) 281-9.

BRUNSDON, C., A. S. FOTHERINGHAM, and M. CHARLTON (1998) Geographically weighted regression- Modelling spatial nonstationarity, The Statistician 47(3) 431-43.

BRUNSDON, C., A. S. FOTHERINGHAM, and M. CHARLTON (1999) Some notes on parametric significance tests for geographically weighted regression, Journal of Regional Science 39(3) 497-524.

BRUNSDON, C., A. S. FOTHERINGHAM, and M. CHARLTON (2002) Geographically weighted summary statistics- A framework for localized exploratory data analysis, Computers, Environment and Urban Systems 26; 501-24. 
BUĞRA, A. (2002) Labour, capital, and religion: Harmony and conflict among the constituency of political Islam in Turkey, Middle Eastern Studies 38(2) 187-204.

CALVO, E. and M. ESCOLAR (2003) The local voter: A geographically weighted approach to ecological inference, American Journal of Political Science 47(1): 189-204.

ÇAHA, Ö. (2003) Turkish Election of November 2002 and the Rise of "Moderate" Political Islam, Alternatives: Turkish Journal of International Relations 2(1) 95-116.

ÇARKOĞLU, A. (2000) The Geography of the Aprill 1999 Turkish Elections, Turkish Studies 1(1) 149-71.

ÇARKOĞLU, A. (2005) Political Preferences of the Turkish Electorate: Reflections of an Alevi-Sunni Cleavage, Turkish Studies 6(2) 273-92.

ÇARKOĞLU, A. and M. J. HINICH (2006) A spatial analysis of Turkish party preferences, Electoral Studies 25(2): 369-92.

ÇINAR, A. and B. ARIKAN (2002) The Nationalist Action Party: Representing the State, the Nation or the Nationalists?, Turkish Studies 3(1) 25-40.

ÇOŞAR, S. and A. ÖZMAN Centre-right politics in Turkey after the November 2002 general election: neo-liberalism with a Muslim Face, Contemporary Politics 10(1) 57-74.

DAĞI, İ. D. (2005) Transformation of Islamic Political Identity in Turkey: Rethinking the West and Westernization, Turkish Studies 6(1) 21-37.

DOĞAN, E. (2005) The Historical and Discoursive Roots of the Justice and Development Party's EU Stance, Turkish Studies 6(3) 421-37.

ERMAN, T. and E. GÖKER (2000) Alevi politics in contemporary Turkey, Middle Eastern Studies 36(4) 99-118.

FARROW, A., C. LARREA, G. HYMANN and G. LEMA (2005) Exploring the spatial variation of food poverty in Ecuador, Food Policy 30; 51031.

FOTHERINGHAM, S., M. CHARLTON, and C. BRUNSDON, (2002) Geographically Weighted Regression, Chichester; John Wiley.

GRUEN, G. E. (2003) Turkey's 'Political Earthquake': Significance for the United States and the Region, American Foregin Policy Interests 25; 87-97.

HALE, W. (2005) Christian Democracy and the AKP: Parallels and Contrasts, Turkish Studies 6(2) 293-310.

HERMANN, R. (2003) Political Islam in Secular Turkey, Islam and ChristianMuslim Relations 14(3) 265-76.

İNSEL, A. (2003) The AKP and normalizing democracy in Turkey, The South Atlantic Quarterly 102(2/3) 293-308.

IŞIK, O. and M. M. PINARCIOĞLU (2006a) Bölgesel siyasi tercihler ve AKP, Toplum ve Bilim, 107: 66-86.

IŞIK, O. and M. M. PINARCIOĞLU (2006b) Geographies of a silent transition: A geographically weighted regression approach to 
regional fertility differences in Turkey, European Journal of Population 22(4) 399-421.

IŞIK, O. and M. M. PINARCIOĞLU (2006c) Ankara 2002 genel seçimleri coğrafyası, in Tansı Şenyapılı (ed.) 'Cumhuriyet'in Ankarası', ODTÜ Yayıncılık, Ankara.

KALAYCIOĞLU, E. (1994) Elections and party preferences in Turkey: Changes and continuities in the 1990s, Comparative Political Studies 27(3) 402-24.

KALAYCIOĞLU, E. (2002) The Motherland party: the challenge of institutionalization in a charismatic leader party, Turkish Studies 3(1) 40-61.

KANRA, B. (2005) Democracy, Islam and Dialogue: The Case of Turkey, Government and Opposition 40(4) 515-39.

MARDIN, S. (1973) Center-periphery relations: A key to Turkish politics?, Daedalus 102(1) 169-90.

MECHAM, Q. R. (2004) From the Ashes of Virtue, a Promise of Light: The Transformation of Political Islam in Turkey, Third World Quarterly 25(2) 339-58.

ÖZBUDUN, E. (1981) The Turkish party system: institutionalization, polarization, factionalization, Middle Eastern Studies 17(2) 228-40.

ÖZBUDUN, E. (2006) From Political Islam to Conservative Democracy: The Case of the Justice and Development Party in Turkey, South European Society \& Politics $11 ; 543-57$.

ÖZEL, S. (2003) Turkey at the Polls: After the Tsunami, Journal of Democracy 14(2) 80-94.

PINARCIOĞLU, M. M. and O. IŞIK (2008) Not only helpless but also hopeless: Changing dynamics of urban poverty in Turkey, European Planning Studies 16(10): 1353-71.

PLATT, R. V. (2004) Global and local analysis of fragmentation in a mountain region of Colorado, Agriculture, Ecosystems and Environment 101; 207-18.

SAYARI, S. (1978) The Turkish party system in transition, Government and Opposition, 13(1) 39-57.

SECOR, A. J. (2001) Ideologies in crisis: Political cleavages and electoral politics in Turkey in the 1990s, Political Geography 20; 539-60.

SMITH, T. W. (2005) Between Allah and Atatürk: Liberal İslam in Turkey, The International Journal of Human Rights, 9(3) 307-25.

TACHAU, F. (1984). Turkey: the politics of authority, democracy, and development, Praeger, New York.

WEST, J. W. (2005) Regional cleavages in Turkish politics: An electoral geography of the 1999 and 2002 National Elections, Political Geography 24; 499-523.

WORLD BANK (2006) Turkey: Labor Market Study, World Bank, Poverty Reduction and Economic Management Unit, Report no: 33254-TR.

YAVUZ, M. H. and ÖZCAN, N. A. (2006) The Kurdish question and Turkey's Justice and Development Party, Middle East Policy 13(1) 10219. 
Alınd1: 12.06.2009, Son Metin: 04.01.2010

Anahtar Sözcükler: Türkiye, coğrafi ağırlıklandırılmış regresyon; merkez-çevre modeli; parti tercihleri; siyasi partiler.

\section{HERŞEYİN DEĞİŞTİĞİ YILA GERİ DÖNÜŞ: 2002 GENEL SEÇIMMLERINNDE PARTİ TERCİHLERİNI YEREL DÜZEYDE BELİRLEYEN ETMENLER}

İslami eğilimleri olan Adalet ve Kalkınma Partisi'nin (AKP) 2002 seçimlerini kazanarak iktidara gelmesi ile birlikte Türkiye siyasetinde çok önemli bir değişim yaşandı. Seçimler Türkiye siyasetini derinden belirleyen "tsunami" etkisi yaratmış olsa da, Türkiye seçim coğrafyasında ortaya çıkan farklılaşmaların ne denli kalıcı olduğunu bir kez daha gözler önüne serdi. Coğrafi ağırlıklandırılmış regresyon olarak bilinen bir teknik yardımıyla bu yazıda, Türkiye'deki eşitsiz seçim coğrafyasının ardında yatan nedenler araştırılmaktadır. Elde edilen sonuçlar Türkiye siyaset sahnesinin iki temel aktörü olan AKP ve CHP'nin oy düzeyini belirleyen yerel etmenler açısından belirgin bir karşıtlık içinde olduklarını ortaya koymaktadır. AKP'nin, geleneksel sağ partilerin tersine, kent yoksulları ile Anadolu' nun hızla gelişen bölgelerinde kendine bir taban bulmuş olmasına karşın, sosyal demokrat CHP büyük ölçüde kentli seçkin kesimlerle kısıtlı kalmış görünmektedir. Bu bulgu, çoğu araştırmacı tarafından Türkiye siyasetinin en belirgin özelliklerinden biri olarak görülen "merkez-çevre" ayrımının yeni bir görüntüsü olarak ele alınmalıdır.

OĞUZ IŞIK; B.CRP., M.CP., Ph.D.

Received his Bachelor and Master's degrees at METU and Ph.D. from University College London, Bartlett School of Architecture and Planning. Currently teaching at City and Regional Planning Department at METU. Has published on urban poverty, residential segregation and electoral geography. ioguz@metu.edu.tr

M. MELİH PINARCIOĞLU; M.Sc., M.RP., Ph.D.

Currently a member of City and Regional Planning Department at METU. Received his Bachelor and Master's degrees at METU and Ph.D. from University College London. His research interests cover rural poverty and regional development. melihp@metu.edu.tr 